\title{
The Correlation Between English Language Education Students' Speaking Anxiety and Their Speaking Fluency
}

\author{
Ni Luh Chandra Ayuni ${ }^{*}$, Ni Luh Putu Eka Sulistia Dewi ${ }^{2}$, A.A Gede Yudha \\ Paramartha $^{3}$ (iD \\ 1,2,3 English Language Education, Universitas Pendidikan Ganesha, Singaraja, Indonesia \\ *Corresponding author: chandraayuni@gmail.com
}

\begin{abstract}
This study aims to analyze the correlation between English Language Education (ELE) students' speaking anxiety and their speaking fluency. This is a quantitative research which consists of 95 students from the $2^{\text {nd }}$ semester as the sample. The data of students' speaking anxiety were collected through questionnaire namely FLCAS (Foreign Language Anxiety) which was adopted from Horwitz and Cope. While the data of speaking fluency were collected by using speaking test. There are two variables in this research, students' speaking anxiety as the independent variable and students' speaking fluency as the dependent variable. The data were analyzed by using SPSS and Pearson Product Moment was used to find out the relationship between the two variables. The result showed that there was a significant and negative correlation between students' speaking anxiety and their speaking fluency. The significant value is $.045<.05$ and the value of correlation is -206 . The negative correlation in this research indicates that there is an inverse correlation between those two variables. The students obtain low level of anxiety and achieved a high-level score in speaking fluency.
\end{abstract}

Keywords: Speaking Anxiety, Speaking Fluency, FLCAS

$\begin{array}{lll}\text { History: } & & \text { Publisher: Undiksha Press } \\ \text { Received } & \text { : September 09, } 2020 & \text { Licensed: This work is licensed under } \\ \text { Revised } & \text { : September 15, 2020 } & \text { a Creative Commons Attribution 3.0 License } \\ \text { Accepted } & \text { : March 17, 2021 } & \text { C. C) O } \\ \text { Published } & \text { : July 25, 2021 }\end{array}$

\section{INTRODUCTION}

Speaking is a way that the speaker uses in transferring their personal or impersonal message to the listener (Dewi, 2017; Sun \& Yang, 2015). Through an active conversation, the speaker can deliver the messages and the message will be received, processed and responded properly by the hearer. People who can communicate language fluently tend to be better in producing sentences for real communication or in reaching their objectives. That is why fluency is one of the essential elements of speaking for students to be successfully acquire the target language (Barrot \& Agdeppa, 2021; Yen et al., 2015). Whereas, it allows students to process information and language spontaneously without putting much effort (Haryudin, 2016; Masuram \& Sripada, 2020). In addition, fluency is related to accuracy and speed in proceeding massage from any resources with appropriate responses (Ardington et al., 2021; Barrot \& Agdeppa, 2021). Furthermore, students who speak English fluently and accurately will have a great chance for better education, jobs and promotion. From explanation above, it can be stated that fluency is needed to be taught to make the learner can speak reasonably, coherently and semantically without breaking down the communication. However, speaking English fluently is seen very difficult for the students. There are some influencing factors and one of them is anxiety (Miskam \& Saidalvi, 2019). Anxiety is physical condition where the subject experiences excessive worries that she/he feels hard to control (Rokach, 2020). It is believed that anxiety has a significant role in debilitating students speaking skill especially towards their speaking fluency.

In addition, some studies also support the role of anxiety on students' speaking fluency. For instance, a study which focused on exploring the factors influence the students' 
English-speaking barriers. The research found that anxiety in forms of nervousness, fear of making mistakes, and lack of confidence were one of the essentials factors contributing to students' speaking barriers (Shen \& Chiu, 2019). A study concerned on the factors influencing students' fluency in English speaking skill. The finding underlined the students' habit which they were commonly speak using their mother tongue (Putri et al., 2020). This had become a great influence for the students where they were then felt shy and reluctant when it comes to speak English. However, there are also some studies showed a different result regarding the influence and correlation between anxiety and speaking performance (Surya, 2017). She found that there is a weak correlation found between anxiety and students' speaking performance. By having this result anxiety is the symptom which occur to the students but only has a bit influence or even no influence in inhibiting students speaking skill. Moreover, there also a study found that even the students obtained anxiety while they are speaking but they still fluent in transferring their ideas through speaking (Marjan, 2016). The results from those studies showed that anxiety is not an affecting factor regarding to the students speaking skill.

Basically, those previous researches were done in a classroom context which only seek the students' anxiety and fluency through the conventional way. Yet, only few researches were found that examined about the anxiety and fluency in online learning context. In fact, the movement on using online learning has grown up rapidly through the world-wide over past decade, which means, it can allow the students to attend classes without needing the physical campus to attend. Further, in 2017 Indonesia put itself into the eight position of the highest demand in using online learning. Meanwhile, the demand in using EdTech in Indonesia shows a massive growth. The market size of the EdTech industry in Indonesia is estimated reaching USD122 million in 2019, and predicted to grow at $24.9 \%$ annually (Factory, 2019; World Bank, 2020). Moreover, during the outbreak disease namely COVID-19 which spread out through the globe at the end of 2019 and still continuously spread out in the middle of 2020 made the government changed the teaching and learning process into online (Alrefaie et al., 2020; Simamora, 2020). As a result Indonesia hit 98\% users in using online learning services (Rizkia, 2020).

The underlying reason that laid back in this learning phenomenon exist on the demand from the society of using internet-based technology in their daily basis. Therefore, the aptitude of the students in using the internet and technology has aroused the institution to offer online program which can help the students to meet their needs in education and economic field from all over the world. Moreover, the Industry 4.0 era also has dragged the curriculum of education oriented on ICT-based learning, internet and computerization (Lase, 2019). Thus, all of the institution in educational field from all around the world has to changed or mix the courses into online courses besides the face-to face meeting. In language learning itself, this transformation into online learning is assumed can help the students to reduce the level of their anxiety in learning the language and it's also beneficial for the teacher to assess their students in learning the language. Since then, many language teachers or instructors turned their way of teaching into online learning. When the nature of language is to communicate it fluently and coherently, the language instructors have to use a creative yet communicative way as their tools in teaching online language course. It believes that video can portray all the illustrative relationship and convey the meaning coherently and more comprehensible. Moreover, asking the students to make video project in language learning can provide the students to get lot of benefits in developing and maximizing their positive confidence and their individual independence.

As can be seen, there are conflicting founding which show how anxiety affecting the speaking fluency of the students through traditional classroom environments but none of them examined the students anxiety and fluency through online learning since nowadays 
online learning is very popular among the students and also the outbreak of Novel COVID-19 has turned the learning process into online. This contrary makes the researcher wants to find out whether there is any significant correlation between anxiety and students' fluency in the faculty of language and art, Ganesha University of Education. Since there is no study mention above has analyzed the students' anxiety and fluency through online environment, the researcher initiatively wants to investigate the correlation between anxiety and speaking fluency of the second semester students in English Language Department from Ganesha University of Education.

\section{MATERIALS AND METHODS}

This research was a quantitative research that used correlational method. The subject of this research were $2^{\text {nd }}$ semester students of English Language Education (ELE) from three different classes, those are C, E, and F class which reached 95 students in English Language Education, Faculty of languages and arts. The study that only focused on one research question which addressed to the correlation between the two variables, ELE students' anxiety and speaking fluency. Two instrument ware used in collecting the data. Those are questionnaire namely FLCAS that used to assess the students' anxiety level and descriptive speaking fluency test which used to measure the students speaking fluency. There were 33 questions that exist in the questionnaire which already passed back to back translation and each item were focused on measuring the speaking anxiety. In speaking fluency, there were five topics given to be chosen with the speaking fluency rubric. The instrument grid is shown in Table 1.

Table 1. Research Instrument Grid

\begin{tabular}{|c|c|c|c|}
\hline No. & Variables & Operational Definition & Indicators/Aspect \\
\hline 1 & $\begin{array}{l}\text { Students' } \\
\text { Anxiety }\end{array}$ & $\begin{array}{l}\text { A distinct complex of self-perceptions, beliefs, } \\
\text { feelings, and behaviors related to classroom } \\
\text { learning arising from the uniqueness of the } \\
\text { language learning process. }\end{array}$ & $\begin{array}{ll}\text { 1. } & \text { Communication } \\
\text { Apprehension } \\
\text { 2. Test Anxiety } \\
\text { 3. Fear of Negative } \\
\text { Evaluation }\end{array}$ \\
\hline 2 & $\begin{array}{l}\text { Speaking } \\
\text { Fluency }\end{array}$ & $\begin{array}{l}\text { The natural ability to speak spontaneously, } \\
\text { quickly and comprehensibly with few numbers of } \\
\text { errors that may distract the listener from the } \\
\text { speaker's message; when accuracy is focus on the } \\
\text { elements of phonology, grammar, and discourse in } \\
\text { spoken output. }\end{array}$ & $\begin{array}{l}\text { 1. Pausing } \\
\text { 2. Rate } \\
\text { 3. Utterance } \\
\text { 4. Volume }\end{array}$ \\
\hline
\end{tabular}

After the two instruments were administered procedurally, the intended data were gathered and analyzed systematically. Firstly, the questionnaire of FLCAS were distributed to the sample through google form and they were asked to fill the form in two days maximum. Secondly, the samples were asked to make the speaking video based on the topic given with the maximum time allocation and upload it through YouTube channel then submit the link video to the researcher. Thirdly, the researcher recap the data from the questionnaire and ask three raters to give the score for the speaking fluency of the students. Finally, the researcher analyzed the data from those two instrument by using Pearson Product Moment through SPSS 16. 


\section{RESULTS AND DISCUSSION}

\section{Results}

The result showed the number of the students who had little or no anxiety reached 82 students or $86.32 \%$ from the sample and 13 students or $13.68 \%$ from the sample were categorized as in the moderate anxiety from the total 95 samples. Moreover, for the speaking fluency, the students were categorized fluent in speaking since most of them $(76,8 \%)$ had obtained a very good scores in average. In addition, there is a significant and negative correlation found between those two variables. The result of the analysis from Pearson product moment coefficient was described as the Table 2 .

Table 2. The Correlation Between Speaking Anxiety and Speaking Fluency

\begin{tabular}{llcc}
\hline Variable & Statistics & FLCAS & Speaking \\
\hline FLCAS & Pearson Correlation & 1 & $-0.206^{*}$ \\
& Sig. (2-tailed) & & 0.045 \\
Speaking & N & 95 & 95 \\
& Pearson Correlation & $-0.206^{*}$ & 1 \\
& Sig. (2-tailed) & 0.045 & \\
& N & 95 & 95 \\
\hline
\end{tabular}

From Table 1, it can be seen that the coefficient correlation or $(r)(-0.206)$ was higher than $r$ table (0.202). The level of significance (sig. 2-tailed) was 0.045 which mean the $p$ value was lower than 0.05 . This result indicates that there is a significant correlation between ELE students' anxiety and their speaking fluency. However, referring to Cohen's effect size interpretation, a coefficient correlation number that reached $0.20-0.35$ point were considered has a small or weak association within variables which means that the result of this study were in a small or weak correlation with the number of correlation -0.206 . In sum, both of FLCAS and speaking fluency is correlated in a negative way ( $\mathrm{r}-\mathrm{xy}=-0.206 ; \alpha=0.045)$. In the other words, the students' speaking fluency get decrease as the anxiety get increase or the students' speaking fluency get increase as the anxiety get decrease.

\section{Discussion}

Since study about correlation which is trying to seek the correlation between English language students' anxiety and their speaking fluency. The discussions are made to strengthen the value from the analysis result. Based on the result, it was found that there is a significant and negative correlation between ELE students' anxiety and their speaking fluency. It indicates that the relation between anxiety and speaking fluency tends to move in opposite directions or simply, when the anxiety get increase, the students' speaking fluency will get decrease or when the anxiety get decrease, the students' speaking fluency will get increase. The negative correlation in this study indicates that the students obtained low anxiety in speaking the language and obtained a high-level score in speaking fluency. For instance, the level of correlation was in a small point or in the weak correlation (-. 206) which means anxiety has low effect to the students' speaking fluency. This small association probably occur because the students already train to speak better English in the university, since the samples were in $2^{\text {nd }}$ semester of English Language Education students. This reason strengthen by the subject that were already taken by the samples, they already passed vocabulary and speaking for informal interaction course which can be assumed that the students already know how to speak properly in English. By this reason, the anxiety from the students in speaking the language can be minimized since anxiety in speaking comes when the students did not have any preparation or did not know what to speak. 
Referring to the result of the analysis from Pearson product moment, it showed that there is a negative and significant correlations between ELE students' with their speaking fluency ( $r x y=-206 ; \alpha=.045$ ). Meanwhile, the negative correlation indicate there is an inverse relationship between those variables which can be assumed that the lower anxiety of the students, the higher fluency they have or the vice versa. The significant correlation in a negative way also strengthens by the result from the anxiety questionnaire which found that 82 students or $86,32 \%$ from the sample experienced a little or no anxiety and only 13 students or $13,68 \%$ who were in the moderate anxiety. On the other hand, the result of speaking fluency showed that $92(96.8 \%)$ students were got a very good score and only $3(3,2 \%)$ students were in a good score categorization.

The negative result occurs due to some affective factors that might be contribute to the students' speaking fluency. For instance, motivation or confidence is one of the factor, which can influence the students during their language learning especially in performing the language. Commonly, it refers to the negative aspects of fear in speaking the language. Specifically, a fear when the students did not know or did not familiar with the topic given. Moreover, fears occur during the students' perception that afraid of making mistakes while they are speaking and afraid the other students will laugh at him or her. In line with it, the students also afraid of looking foolish by the other students and being evaluated by the teacher while they are not ready enough to speak in front of the class. In sum, even the students do have proficiency in speaking they will still experience a little anxiety during their speaking performance. This statement proven by the students' speaking anxiety that was considered in low level. There also another factors that contribute to their speaking fluency. Those factors could be the cognitive factors which include conceptualization, formulation and articulation. Linguistic factors which refers to pronunciation, grammar and vocabulary. Last one is affective factors, such as risk-taking and motivation. In addition, Classroom atmosphere, students' self-esteem, group work and motivation also some factors that contribute to speaking fluency. The online learning also believed can reduce the anxiety level of the students during learning the language and change their attitude towards language learning.

Affective factors itself relate to the emotional feeling from human behavior that vary from one person to another person personality based on with whom they interact with. In addition, affect itself refers to emotions, feelings, beliefs, moods and attitude that could greatly effect human behavior. It can be said that affective factors are the emotions, feelings, beliefs and attitude from someone that can highly effect their personal behavior. Moreover, motivation which is one of the specific affective factors has its own role in impacting students' speaking skill. Motivations refers to students efforts, desire and good attitudes while trying to achieve the learning objectives in learning process (Li et al., 2020; Y. H. Wang et al., 2020). Moreover, motivations also can be referred to someone feeling in forcing themselves to achieve their own goals (Bonk \& Lee, 2017; Ryan \& Deci, 2020). Therefore, students who have a lack of motivation will more closely fail in achieving their goals in speaking. Risk-taking and self-esteem are also the crucial part in affective factors that could affect students' speaking skill especially their fluency. Being able to take the risk in learning language is one of the best effort to do. Make mistake and being wrong are common thing in learning especially speaking the language. The students can expose them self as much as possible to know their deficiency in speaking. Their trial, error and process are the thing that being needed to measure their development in becoming fluent speaker. In taking a risk, the students also have to have a high self-esteem to make the practice more and more. Selfesteem refers to the personal beliefs of the students towards themselves (Mitha et al., 2018; Y. Wang et al., 2021). Students who have willingness in taking the risk and also have a high self-esteem are closely to achieve their goals in becoming a fluent speaker. On the contrary, 
students who have a low self-esteem and do not want to take a risk in learning the language are way too hard in becoming fluent in speaking.

In sum, the teacher roles in providing a good classroom atmosphere also becomes a factor in which support their students speaking achievement especially in speaking fluency. A good classroom atmosphere will boost the students' motivation and mood during learning process. For instance, when the atmosphere in the classroom are not too good, it will directly influence the students learning motivation. Moreover, the students' speaking fluency are considered as in a high level since their scores are mostly in a very good categorization. On the other hand, the assessment of the speaking fluency were through the video and the students can choose the topic that they think the best to describe it can be assumed that the students feel comfortable in speaking the topic chosen. The students will enjoy talking as native speaker when they are feel comfortable and got a lot motivation from their surroundings. They also had a lot of time to prepare their self to speak. The sample that were taken are from the English major which already passed the vocabulary and speaking for informal interactions. This condition can be assumed as the factor that contribute to the reason why the samples got a very good score in term of speaking fluency.

The result of this research is in agreement with the previous study which found that there was a significant correlation between anxiety and speaking skill at STKIP Kusuma Negara Jakarta $(0.001<0.05)$ with the correlation value was -0.629 or it could be mean correlated in a negative way(Megawati, 2019). This founding indicates that Ha was accepted while Ho was rejected with the significant values $0.001<0.05)$. The negative correlation in this study indicates that if anxiety goes up then the speaking skill tends to go down. The students will achieve a bad score in speaking while they are cannot confront their anxiety and try to reduce it. However, if the students can reduce their anxiety and step aside their negative feeling while learning the language, they will achieve the good score in speaking. This study found that the most factor that influence students' anxiety was the low self-confidence of the students and beliefs of the students. The student's beliefs that their friends will laugh at him/her when they are asked to speak in front of the class and make them not confidence enough to speak the language.

Moreover, a same result of the study also found by Subekti (2018). The study entitled "Investigating relationship between foreign language anxiety and oral performance of nonEnglish major university students in Indonesia" found a significant correlation in a negative way $(\mathrm{rxy}=-.339)$. This result believed that anxiety has a major role in influencing the students' speaking achievement. The negative correlation in this study indicates that the more anxious the students in speaking the language, the lower score will be achieved in speaking achievement. The students tend to be more passive when they obtain lot of anxiety. Anxiety will appear during their uncomfortable situation and not ready to catch the topic in speaking section. Furthermore, there also a study found that there was a strong negative correlation between students' anxiety and speaking ability, $(\mathrm{r}=-730)$ (Izumi et al., 2017). The negative correlation showed that the students obtain a high anxiety and low speaking achievement. From this result, it can be said that students' anxiety affected the students speaking performance. It also found that the highest score was in the fear of negative evaluation aspect which means that this aspect is the most aspect that affect the students speaking performance into low achievement.

In sum, the total study between anxiety and speaking showed a negative and significant correlation which means that there is an inverse relationship between two variables. In this case the variable $\mathrm{X}$ (anxiety) will go up when variable $\mathrm{Y}$ (speaking) tends to go down or the vice versa. If the students' anxiety goes up and the speaking achievement goes down, it indicates that the students cannot minimize the anxiety or the aspects in the anxiety itself. Whereas, if the students obtained low anxiety and obtained high speaking 
achievement then it can be said that the students can handle their anxiety or other factors that contribute more in their speaking achievement. Finally, this study found that there is a negative and significant correlation between ELE students' anxiety and their speaking fluency. The negative correlation in this study indicates that the students obtained low anxiety in speaking the language and obtained a high-level score in speaking fluency. This negative result might be occurred because of some factors that contribute to their speaking fluency besides anxiety, such as the other affective factor: motivation, self-esteem and risk taking. Moreover, online learning atmosphere also a probable factor that contribute to students' speaking fluency which is believed can reduce students' anxiety level. The difference significance of this study with the other study which seek the same field lied to the samples that were used. This study used the university students as the sample while the other used senior high school students as the sample. Furthermore, this research used fluency as the second variable while the others used to speak in general as the second variable, which can be assumed this research is, specifically significant to the speaking fluency while the other researches significant to the speaking in general.

There are some weakness that occur during conducting this study, which may influence the result of the study. The weaknesses could be the limitation of the sample in this research that only in the three intact classes of the $2^{\text {nd }}$ semester students of English Language Education (ELE) in Ganesha University of Education. So that, the result that were obtained may showed a difference when the same study was conducted in different sample. The other weaknesses might be laid up in the method of collecting data. Since every data were collected through online questionnaire and video there could be a different result found if the data were taken directly. Moreover, the variable that was used in this study were not represent all the factors in the speaking, which can cause the different result for another factors.

\section{CONCLUSION}

This research shows a negative correlation between the two examined variables. The result shown that the students obtained high level speaking fluency score as they experienced low level of anxiety. This research shall give contribution to English language students as their reflection in knowing their level of anxiety and which factor might contribute to it. Furthermore, to the language educator can use this research as guidance in creating language material, which can reduce students' speaking anxiety. However, it is important to note that this research was taken only in English language education department and completely done through online examination, which might be derived different result if it were conducted in another department, and done through direct examination. Therefore, the writer respectfully suggests to the reader not to generalize the result and shall use this research as reference in conducting the same field of research.

\section{ACKNOWLEDGMENTS}

The author would express her grateful to all parties who are involved in this research including the two supervisors, parents and all of author's supportive friends. The author realize that this study so far from perfection. Therefore, the author welcomes any constructive criticism and suggestions to make this study better.

\section{REFERENCES}

Alrefaie, Z., Hassanien, M., \& Al-Hayani, A. (2020). Monitoring Online Learning During COVID-19 Pandemic; Suggested Online Learning Portfolio (COVID-19 OLP). 
MedEdPublish, 9(1), 1-4. https://doi.org/10.15694/mep.2020.000110.1.

Ardington, C., Wills, G., Pretorius, E., Mohohlwane, N., \& Menendez, A. (2021). Benchmarking oral reading fluency in the early grades in Nguni languages. International Journal of Educational Development, 84, 102433. https://doi.org/10.1016/j.ijedudev.2021.102433.

Barrot, J. S., \& Agdeppa, J. Y. (2021). Complexity, accuracy, and fluency as indices of college-level L2 writers' proficiency. Assessing Writing, 47, 100510. https://doi.org/10.1016/j.asw.2020.100510.

Bonk, C. J., \& Lee, M. M. (2017). Motivations, Achievements, and Challenges of SelfDirected Informal Learners in Open Educational Environments and MOOCs. Journal of Learning for Development, 4(1), 36-57. https://j14d.org/index.php/ej14d/article/download/195/188?inline=1 .

Dewi, C. (2017). Peningkatan Keterampilan Berbicara Dalam Bermain Drama Melalui Model Pembelajaran Kooperatif Tipe Inside-Outside Circle. JINoP (Jurnal Inovasi Pembelajaran), 3(2), 567. https://doi.org/10.22219/jinop.v3i2.4575.

Haryudin, A. (2016). the Students' English Speaking Competence Based on Ktsp Curriculum. Eltin Journal, Journal Of English Language Teaching In Indonesia, 4(2), 1-12. http://e-journal.stkipsiliwangi.ac.id/index.php/eltin/article/download/375/623.

Izumi, G. C., Setiyadi, A. B., \& Supriyadi, D. (2017). The Study between Students' Anxiety and Speaking Ability at SMAN 1 Kabupaten Tangerang. U-JET, 6(7). https://core.ac.uk/download/pdf/291528982.pdf.

Lase, D. (2019). Education and industrial revolution 4.0. Jurnal Handayani Pgsd Fip Unimed, 10(1), 48-62. https://jurnal.unimed.ac.id/2012/index.php/handayani/article/view/14138.

Li, H., Peng, M. Y.-P., Yang, M., \& Chen, C.-C. (2020). Exploring the Influence of Learning Motivation and Socioeconomic Status on College Using Self-Determination Theory. Frontiers in Psychology, 11, 1-13. https://doi.org/10.3389/fpsyg.2020.00849.

Masuram, J., \& Sripada, P. N. (2020). Developing speaking skills through task-based materials. Procedia Computer Science, 172(2019), 60-65. https://doi.org/10.1016/j.procs.2020.05.009.

Megawati, M. (2019). The Correlation Between Students'anxiety And Speaking Skill At Stkip Kusuma Negara Jakarta (A survey research first semester academic year 2018/2019). Scope: Journal of English Language Teaching,3(2), 117-122. https://journal.lppmunindra.ac.id/index.php/SCOPE/article/view/3384.

Miskam, N. N., \& Saidalvi, A. (2019). Investigating English language speaking anxiety among Malaysian undergraduate learners. Asian Social Science, 15(1), 1-7. https://pdfs.semanticscholar.org/10e7/2d0dcf0282a72eae4530173babad88ab9f5a.pdf.

Mitha, W. D., Amri, Z., \& Narius, D. (2018). An Analysis of Students' Speaking Anxiety Faced by the Fourth Semester Students of English Education Study Program of English Departement of Universitas Negeri Padang. Journal of English Language Teaching, 7(3), 1-15. http://ejournal.unp.ac.id/index.php/jelt/article/view/100269.

Putri, M., Ariyani Pedo, V., \& Pawestri, N. (2020). Analyzing the Factors Influencing Students' Fluency in English Speaking Skills: A Case in Bina Nusantara University. ICLLT 2019. https://doi.org/10.4108/eai.12-10-2019.2292184.

Rokach, A. (2014). Loneliness of the marginalized. Open Journal of Depression, 2014. https://www.scirp.org/html/3-2720051_49163.htm?pagespeed=noscript.

Ryan, R. M., \& Deci, E. L. (2020). Intrinsic and extrinsic motivation from a selfdetermination theory perspective: Definitions, theory, practices, and future directions. Contemporary Educational Psychology, 61, 1-31. https://www.sciencedirect.com/science/article/pii/S0361476X20300254. 
Shen, M., \& Chiu, T. (2019). EFL Learners' English Speaking Difficulties and Strategy Use. Education and Linguistics Research, 5(2), 88. https://doi.org/10.5296/elr.v5i2.15333.

Simamora, R. M. (2020). The Challenges of Online Learning during the COVID-19 Pandemic: An Essay Analysis of Performing Arts Education Students. Studies in Learning and Teaching, 1(2), 86-103. https://doi.org/10.46627/silet.v1i2.38.

Sun, Y. C., \& Yang, F. Y. (2015). I help, therefore, I learn: service learning on Web 2.0 in an EFL speaking class. Computer Assisted Language Learning, 28(3), 202-219. https://doi.org/10.1080/09588221.2013.818555.

Surya, A. M. (2017). A Correlation Between The Students' Speaking Anxiety and Fluency. State Institutes of Islamic Studies (IAIN) Salatiga.

Wang, Y. H., Chang, M. C., \& Liou, J. R. (2020). Comparison of the effectiveness of Taiwanese college and high school students participating in creative contests. Thinking Skills and Creativity, 38. https://doi.org/10.1016/j.tsc.2020.100717.

Wang, Y., Huebner, E. S., \& Tian, L. (2021). Parent-child cohesion, self-esteem, and academic achievement: The longitudinal relations among elementary school students. $\begin{array}{llll}\text { Learning and Instruction, } & 701467 .\end{array}$ https://doi.org/10.1016/j.learninstruc.2021.101467.

Yen, Y. C., Hou, H. T., \& Chang, K. E. (2015). Applying role-playing strategy to enhance learners' writing and speaking skills in EFL courses using Facebook and Skype as learning tools: a case study in Taiwan. Computer Assisted Language Learning, 28(5), 383-406. https://doi.org/10.1080/09588221.2013.839568. 